\title{
28 Research Soure \\ Geothermal Renewable Energy Prospects of The African Continent Using GIS
}

\section{Samah Elbarbary}

National Research Institute of Astronomy and Geophysics (NRIAG)

Mohamed Abdel Zaher ( $\nabla$ moh_zaher@yahoo.com )

National Research Institute of Astronomy and Geophysics (NRIAG) https://orcid.org/0000-0002-4443-

4770

\section{Hakim Saibi}

United Arab Emirates University

Abdel-Rahman Fowler

United Arab Emirates University

Kamal Saibi

Kyushu University

\section{Research Article}

Keywords: geothermal energy, geothermal potential, Africa, GIS model, potential map.

Posted Date: February 1st, 2022

DOI: https://doi.org/10.21203/rs.3.rs-1298799/v1

License: (c) (i) This work is licensed under a Creative Commons Attribution 4.0 International License.

Read Full License 


\section{Abstract}

Geothermal energy potential is identified through the deep investigation of geological, geothermal, and geophysical information over a small area; however, this task is both expensive and complex. Geographic Information Systems (GIS) can integrate different types of data (or thematic layers) over large regions and use them to identify regions of high geothermal potential. In this study, a GIS tool is used to construct the first regional-scale geothermal potential map of Africa from different datasets. The key objective of this study is to estimate the geothermally promising areas within Africa by integrating geological thematic layers (rock units and faults), geophysical layers (heat flow derived from aeromagnetic data and seismicity), and geothermal layers (hot springs and volcanoes) within the GIS database. A weighted overlay technique within the GIS environment is applied to these data to generate the geothermal potential map.

The result shows 14 regions with a high geothermal favorability index. The geothermal potential map of Africa is useful for targeting and exploring new geothermal renewable energy sites and can reduce exploration costs and pinpoint investigation areas during preliminary geothermal studies.

\section{Highlights}

- The first geothermal potential map of Africa was constructed using GIS.

- A weighted overlay method was used to integrate various geo-datasets.

- The geothermal favorability map of Africa detected 14 high potential zones.

\section{Introduction}

Africa is the world's second-largest continent after Asia and comprises 63 political territories, covering around one-fifth of the Earth's land surface. It is bordered on the east by the Indian Ocean and Red Sea, on the west by the Atlantic Ocean, to the north by the Mediterranean Sea, and to the south by the meeting of Indian and Atlantic Oceans (Figure 1). With the cost of petroleum resources soaring and the critical need to battle climate change, there is broad acceptance that African countries need to adopt new strategies to satisfy their energy demands by using renewable energy resources. Thus, geothermally active areas of Africa have great potential to provide vital energy resources to the continent. The utilization of renewable energy in general (particularly geothermal energy) has allowed African countries to shift their policies towards energy independence and reduce costly energy imports. Geothermal energy is considered to be clean, virtually inexhaustible, and with much less negative environmental impact compared to hydrocarbons.

At present, East African economies are using available geothermal resources to generate an estimated $630 \mathrm{MW}$ of power annually. Kenya is the African leader for operational geothermal power plants, with its geothermal power production totaling more than $40 \%$ of the country's total electricity production. Kenya 
launched an investigation into geothermal energy during the late 1970s. As indicated by the Geothermal Council Resource, Kenya's progress in geothermal applications is within the top ten ranks in the world.

(Figure 1)

There are several stages of scientific investigation preceding the development of any geothermal project. The exploration stages include: geological field surveys (basic geology and structural geology); in situ measurements of geothermal properties (temperature, $\mathrm{pH}$, and flow); geophysical surveys (gravity, magnetics, and magnetotellurics); hydrochemistry of naturally heated waters; and numerical modeling. These approaches usually require deep well data to constrain the models, which is often limited in availability and extremely costly to acquire. To overcome these limitations, in this study, we instead use a weighted overlay method based on GIS, which helps assess regions for geothermal energy potential by integrating different types of geothermal data and applying weighting to different factors connected to geothermal energy output. This approach has been used by many authors, who have demonstrated its applicability in geothermal fields around the world. For example, in Mexico, geothermal zones were evaluated by integrating geological and geophysical data using a GIS-based approach at Los Azufres (Prol-Ledesma, 2000). In Indonesia, a GIS model was developed for mapping the potential of geothermal resources in West Java (Carranza et al., 2008). In Japan, the geothermal positivity map for Iwate and Akita in Northern Japan was created utilizing a GIS-based weighted overlay model applied to constrain geologically, thermally, and geochemically suitable areas (Noorollahi et al., 2007). In Turkey, the weighted overlay technique was used to map the geothermal favorability of Western Anatolia using geothermal and earthquake epicenter datasets, tectonic lineament maps, and magnetic anomaly thematic layers (TL) of evidence (Tüfekci et al., 2010). In addition, in the Akarcay Basin (Turkey), a GIS-based Minor Civil Division method was applied using surface temperature, density, and land surface proximity to current geothermal geological fields, geothermal surface manifestations, and active faults (Yalcin et al., 2017). In Italy, a data integration tool using GIS was described to build up a map of the geothermal favorability of Sicily, southern Italy (Trumpy et al., 2015). More recently, in Egypt, a GIS-based weighted overlay technique was applied to produce geothermal favorability maps using different datasets including tectonic lineament data, temperature logs, and geophysical potential field data (Abdel Zaher et al., 2018, Abuzied et al., 2020, Abdel-Fattah et al., 2021).

The direct investigation and exploitation of geothermal resources involve potentially enormous costs due to the expense of drilling; therefore, prospecting for geothermal resources usually instead relies on indirect investigation through geological and geophysical examinations, which give a generalized perspective of the subsurface conditions. This study demonstrates the utilization of a GIS-based approach in geothermal investigation by integrating constraints from different datasets such as the distribution of geothermal manifestations (volcanoes, hot springs, and geysers), rock types, tectonics, and geophysical data (airborne magnetic and seismic activity data). These datasets are combined into several TL of evidence utilizing a GIS environment, which is used to map the geothermal potential of the African continent, showing the priority zones for possible geothermal exploitation. The input evidence 
layers in the GIS model are rock types, faults, surface manifestations, seismic activity, and heat flow map derived from the aeromagnetic map of Africa.

This study is, to our knowledge, the first to explore the geothermal potential of the African continent using a GIS-based model. This research will help future geothermal investigation studies by better targeting of study areas. The uniqueness and novelty of this approach is that it enables the geothermal potential to be assessed over a broad geographic area using relevant data derived from a GIS-based model, as opposed to costly and spatially limited borehole-based investigation techniques. Furthermore, the developed GIS model is flexible and can be adapted to accept future changes by integrating new geoscientific data as it becomes available and applying simple reclassifications to produce a potentiality map for any part of Africa. Site selection of geothermal resources is certainly not a simple task - it is complex and involves a diverse criterion for appropriate selection, however, our proposed model represents a powerful tool to aid in site suitability prediction.

\section{Methodology}

GIS has an extremely diverse range of applications in fields of study related to spatial information. In particular, in the context of this study, GIS-based resource evaluation is a significant and generally economical tool for distinguishing areas of interest for geothermal investigation. GIS allows different layers of spatial data to be examined and provides tools for investigating and displaying the interrelationships between TL. Recently, GIS-based multi-criteria decision analysis (MCDA) techniques have been widely utilized to produce geothermal suitability maps (e.g., Tüfekci et al., 2010, Noorollahi et al., 2007, Trumpy et al., 2015, Abdel Zaher et al., 2018, Abuzied et al., 2020). MCDA methods involve weighted and fuzzy overlay techniques. Fuzzy logic overlay analyses follow the same general steps as weighted overlay analysis, but with additional emphasis on certain steps. For example, in the fuzzy overlay method, the input is transformed (i.e., scaled) and the resulting values define the possibility of membership in multiple sets, whereas, the weighted overlay method uses a relative preference scale and weights each input accordingly (Esri, 2020). The weighted overlay technique avoids the risk of disregarding potential sites because of sharp limits between spatial classes; furthermore, it gives clearer outcomes and provides reliable assessments from unsatisfactory to reasonable sites (Aliki and Hatzichristos, 2019). The weighted overlay model allows various issues to be considered that are affected by multiple factors with different weights applied to each of them. The outcomes are expected to give a more in-depth assessment and provide more detailed information, as the weighting method ranks areas based on their appropriateness.

In this study, a GIS-based MCDA technique and a weighted overlay method are used to integrate various datasets, including geological, geophysical, and surface manifestations of geothermal activity. The data was processed digitally to constitute five criteria layers: distance to fault lines, geologic units, distance to surface manifestations (i.e., hot springs, volcanoes, and geysers), distance to seismic epicenters, and the value of heat flow, as derived from aeromagnetic data. An analytic hierarchy process (AHP) method was applied to weight each criterion. This is followed by combining each standardized, weighted layer, using 
the GIS to gain an overall geothermal potential map. The results were verified using comparison with the locations of known geothermal wells. Figure 2 shows a workflow chart of the input data and the process of defining the geothermal potentiality map of the African continent.

(Figure 2)

\section{Criteria Standardization}

Standardization of criteria is the first step in preparing the raster layers. In this approach, the user-selected layers are assigned a common numeric range by classifying their attributes into discrete classes. In this paper, criteria layers were attributed to different classes on a scale from 1 to 9 , based on the decision maker's experience-based suitability evaluation. The lower values represent less favorable areas, while higher values represent areas of greater geothermal potential.

\section{Criteria Weight Assignment}

An important step includes the assignment of criteria weighting coefficients. The analytic hierarchy process (AHP) is the most frequently used method for weighting coefficient calculation (Bana e Costa, 2016; Meng et al., 2021; Saaty, 1977). Saaty's (1977) method was applied to compare the evaluation index and to study its importance (Table 1). The established model helps to estimate the weighting for each index. A matrix is constructed according to Saaty (1994) which helps to determine the importance of the layer's elements using the following equation:

$$
\mathrm{x}=\left[\begin{array}{cccc}
x_{11} & x_{12} & \ldots & x_{1 n} \\
\vdots & \vdots & & \vdots \\
x_{n 1} & x_{n 2} & \ldots & x_{n n}
\end{array}\right]
$$

where $x_{i j},(i, j=1,2,3, \ldots, n)$ is the ratio of the importance of criteria $i$ to that of criteria $j$.

The geometric mean method (Perzina and Ramíka, 2014) was used to calculate the weights of each individual criterion based on the values in the pairwise comparison matrix. The consistency index $(\mathrm{Cl})$ of the evaluation matrix is defined as follows:

$$
\mathrm{CI}=\left(\lambda_{\max }-\mathrm{n}\right) /(\mathrm{n}-1)
$$

where $\mathrm{n}$ is the order of the pairwise comparison matrix and $\lambda_{\max }$ is the highest eigenvalue of the matrix. Then the consistency ratio (CR) is calculated via the following equation:

$$
\mathrm{CR}=\mathrm{CI} / \mathrm{RI}(3)
$$


where $\mathrm{RI}$ is represented by average $\mathrm{Cl}$ values gathered from a randomly generated pairwise comparison matrix. The use of $\mathrm{CR}$ allows one to evaluate inconsistency regarding the judgments within the comparison matrix. The suggested value of the CR should be no higher than 0.1 (Saaty, 1988); if the CR value is less than 0.1 , this indicates that the judgments were consistent.

The MCDA GIS method model is developed with on overlapping multiple criteria layers after multiplying the standardized layers by their corresponding weights. The adding of the processed grid layers leads to a composite value that represents the geothermal potential map for the entire study area.

(Table 1)

\section{Analyses of thematic layers $(T L)$ of evidence}

\section{Geological and Structural TL}

The first TL of evidence is obtained from the lithological and structural map of Africa, which provides evidence of the genesis of geothermal phenomena. The distribution of the Phanerozoic and Precambrian rocks was digitized from the geological map of Africa (Figure 3) at a scale of 1:10 million (Thiéblemont et al., 2016). Young volcanoes or volcanic rocks of Pleistocene-Recent age may act as a heat source, while the presence of faults and fractures creates fluid pathways (Poux and Suemnicht, 2012). Pleistocene-age volcanic rocks were also integrated into the geological and structural TL (Persits et al., 1997), as they have a strong correlation with the geothermal manifestations of northern Algeria and eastern Africa.

Regionally continuous basement exposures exist in the eastern part of the African continent along the East African Rift System (EARS) and the western coast of the Red Sea, the eastern coast of the Atlantic Ocean, in the western craton of the African continent, and East Madagascar. The crystalline basement rocks of Africa contain three significant associations: (1) the granite-gneiss-greenstone and other highgrade metamorphic assemblages which make up the Archaean cratons; (2) strongly deformed mobile belts (mostly of Proterozoic age); and (3) anorogenic intrusions and extrusive products, which include riftrelated Phanerozoic magmatic and volcanic rocks (Key, 1992). South Africa also has an abundance of granites and gneisses of different ages and chemical compositions, a large portion of which show anomalous radioactivity and above-average heat flow. Despite the influence of basement rock lithology, the presence of intensive zones of rock fracturing and faulting is the main control on the activity of geothermal fluids. These faults are mostly associated with recent tectonic events in the African Plate, in particular, Cenozoic faulting along tensional fractures of the EARS.

(Figure 3)

Faults and fractures are important in controlling geothermal potential since hydrothermal fluids migrate most effectively through faults (Hanano, 2000). Faults on the geological map of Africa (Thiéblemont et al., 2016; Meghraoui et al., 2016) were collected and digitized (Figure 3). Much of the geothermal activity in Africa is concentrated in the east of the continent around the EARS, where continental rifting is associated with geothermal systems with magmatic and volcanic heat sources. The EARS is one of the 
most major active extensional tectonic regimes on Earth; the area is characterized by prominent geothermal potential spatially associated with the Quaternary volcanoes and geysers located along the rift axis.

\section{Volcanic and Geothermal Surface Manifestations TL}

All available surface data related to geothermal activity were collected to characterize the geothermal systems. These data comprise all geothermal manifestations (i.e., volcanoes, hot springs, and geysers) (Figure 1). The hot spring locations in Africa were gathered from diverse sources (Ait Ouali et al., 2019; Waring, 1983; Saibi et al., 2006) and were merged in the GIS model. These surface manifestations were used as the fourth TL of evidence in the GIS model. Volcanic elements such as craters, calderas, and active or young volcanoes are also direct indicators for the existence of an underground heat source. The south and north of Africa have not been considered until now as feasible areas for geothermal energy production due to their tectonic stability (Dhansay et al., 2014; Enerdata, 2013); however, some countries in the north and south of Africa (e.g., Egypt, north Algeria, and South Africa) have surface thermal manifestations, such as hot springs of various temperatures.

The United Nations Environment Program and the Infrastructure Consortium for Africa estimate a geothermal potential capacity of more than $20 \mathrm{GW}$ of geothermal energy across Eastern Africa (Teklemariam, 2018), which has encouraged countries, including Comoros, Eritrea, Djibouti, Rwanda, Uganda, and Tanzania, to conduct preliminary investigations for geothermal resources. Ethiopia has a future plan to reach $1 \mathrm{GW}$ production from geothermal energy by 2021. Additionally, Uganda, Burundi, and Zambia are working to establish new small-scale geothermal power plants (Hafner et al., 2018). Table 2 summarizes the geothermal activities, temperature gradients, and heat flows of different African countries, compiled from the previous literature.

(Table 2)

\section{Seismic Activity TL}

The seismic database of Africa was obtained from numerous sources, including the United States Geological Survey (USGS) (https://earthquake.usgs.gov/earthquakes), the International Seismological Center (ISC) (http://www.isc.ac.uk) and the Egyptian Seismological Center (ENSN, 2014) (Figure 4). "Seismic events" or epicenters refer to the existence of active faults which, as noted above, play an important role in geothermal systems by providing the permeability pathways required to bring waters heated at depth to close to the surface.

(Figure 4)

The distance to seismic activity (epicenters) was utilized as the fifth TL of evidence to map the geothermal potential of Africa. The African plate experiences frequent seismic events, the most recent of which are principally situated along rift zones, active volcanic fields, thrust and fold mountain belts, and 
offshore transform faults. Some regions in Africa are relatively aseismic, whereas, others have experienced disastrous seismic events. The most conspicuous tectonically active structures are located in the east of Africa, where the intracontinental EARS is located (Kebede \& Kulhanek 1991; Ring, 2014). This rift system is the source of most earthquakes in the African continent and extends from the Afar Triangle through Ethiopia to Mozambique; these areas have been volcanically and magmatically active since rifting began in the Miocene (Wafula, 2011). In contrast, the western and central regions of Africa show generally subdued seismicity.

\section{Heat Flow TL Calculated from Magnetic Data}

The aeromagnetic map of Africa was used to calculate the regional Curie Point Depth (CPD) and geothermal structure in the form of the heat flow map of Africa using the spectral centroid technique. Aeromagnetic information was acquired from the various datasets that were combined under the "African Magnetic Mapping Project" (AMMP) (Getech, 1992; Green et al., 1992). The CPD, which is the depth at which ferromagnetic properties of minerals change to paramagnetic due to rising temperature $\left(>500^{\circ} \mathrm{C}\right)$, was estimated using the centroid technique which involves spectral analysis of the aeromagnetic data (using a window size of $1000 \mathrm{~km}^{2}$ ). The centroid technique depends on the appraisal of separated magnetic anomalies and the statistics of magnetic groups (Spector and Grant, 1970; Bhattacharyya and Leu, 1977). The depth to the top of the magnetic source $\left(Z_{t}\right)$ is computed from the slope of the longest wavelength portion of the spectrum, and the depth to the centroid $\left(Z_{0}\right)$ is calculated from the spectrum divided by the wavenumber " $|\mathrm{k}|$ ". The base of the magnetic source $\left(\mathrm{Z}_{\mathrm{b}}\right)$, assumed to be the $C P D$, can then be obtained from the equation $Z_{b}=2 Z_{o}-Z_{t}$ (Okubo et al., 1985).

The temperature gradient was calculated using the basal depth $Z_{b}$ and the Curie point temperature of 580 ${ }^{\circ} \mathrm{C}: \mathrm{dT} / \mathrm{dz}=580^{\circ} \mathrm{C} / \mathrm{Z}_{\mathrm{b}}$ (Maden, 2010). The heat flow map of Africa (Figure 5) was then computed using the formula: $q=\lambda(d T / d Z)=\lambda\left(580^{\circ} \mathrm{C} / Z_{b}\right)$; where $\lambda$ is the coefficient of thermal conductivity (assumed to be $2.0 \mathrm{~W} / \mathrm{m}^{\circ} \mathrm{C}$, which is representative of Precambrian lower crust (Seipold, 1992)). The calculated heat flow values from borehole bottom hole temperatures for 23 African countries were compared with the values derived from CPDs in order to confirm the results (Figure 5). This comparison showed an overall coefficient of correlation of 0.7. The highest heat flows are found over the eastern part of the African continent and relate to the Afar Triangle and EARS, which comprise highly volcanic areas. High heat flows continue northwards along the Red Sea rift, but also southwards to the Kalahari craton. The northwestern margin of Africa bordering the Atlas Mountains is also a broad area of high heat flow. Individual intracontinental hotspots correspond to plume activity in the Tibesti (Chad) and Darfur (Sudan) regions.

(Figure 5)

\section{Results And Discussion}


The compilation of a geothermal potential map of Africa comprises two main stages. The first stage is the identification of the main sources of evidence that predict geothermal potentiality; the second stage is then the preparation of thematic maps for each of these pieces of evidence. The five prepared thematic maps (i.e., geothermal surface manifestations, geological maps, faults, seismic activity map, and heat flow map) were used as ArcGIS model inputs. All TLs were inserted into the ArcGIS geodatabase and interpolated using the natural neighboring technique which is a weighted-average interpolation approach that generates natural neighborhood zones around each point in the dataset. The TLs were then reclassified to a common suitability scale (from 1 to 9) where higher rates indicate greater geothermal potentiality. The geothermal potential depends upon the threshold values of every parameter, as dictated by the AHP-derived weighting values.

The geothermal surface manifestation layers include a "distance to volcanic activity" layer and a "distance to hot springs and geysers" layer. Each of these layers is separated into two classes. In areas close to these features, a value of 9 was assigned; the greater the distance from the geothermal surface manifestation, the less the influence, and, beyond a threshold distance, a smaller value of 1 was applied. Noorollahi et al. (2007) showed that nearly all (97\%) of geothermal wells are situated within $4 \mathrm{~km}$ of hot springs in Northern Japan. However, to reduce the chance of disregarding potentially promising geothermal zones, we have assumed that the geothermal surface manifestations recorded are restricted to a region of 5 by $5 \mathrm{~km}$. Thus, distances less than $5 \mathrm{~km}$ (a similar distance to that used by Yousefi et al. (2010) for hot springs in Iran) are considered as close to a geothermal feature, resulting in the assignment of the highest value of 9 for this parameter.

The geological maps include lithological data and "distance to faults" data as two separate GIS layers. For the lithological layer, sedimentary rocks generally have low thermal conductivity values compared to volcanic and basement rocks, therefore, they are assigned a lower value on the potentiality scale. Volcanic and basement rocks have higher thermal conductivity and correspondingly higher geothermal potential (assigned as class 8 for basement rocks and class 9 for volcanic rocks). In geothermal areas, fractures and faults are crucial because they control the subsurface movement of fluids. In previous studies, Noorollahi et al. (2007) found that around $95 \%$ of geothermal wells are situated within $6 \mathrm{~km}$ of regional faults in Japan and Yousefi et al. (2010) used the same distance to develop a geothermal resource map of Iran. Accordingly, similar to the geothermal surface manifestations TL above, the "distance to faults" data layer is quantified as a scale of two classes -locations less than $6000 \mathrm{~m}$ from faults are assigned the highest value (9).

The geophysical data comprise the "distance to seismic activity" layer and the "heat flow calculated from the CPD" layer. The "distance to seismic activity" layer is treated the same way as the distance to faults layer; earthquake foci that have depths less than $10 \mathrm{~km}$ are classified into two classes. As the distance from the epicenter of the earthquake increases $(>6000 \mathrm{~m})$, the influence on geothermal activity decreases, and, thus, a lower class is identified. Regarding the higher heat flow layer value, the more geothermally promising an area is, and higher potentiality classes are assigned accordingly. 
After standardization of each layer to a scale from 1 to 9, the five criteria layers can be compared (Fig. 6). According to the previously determined evaluation ranking of the indices, the judgment pairwise matrix was attained (see methodology section) and the weight of each layer was estimated (Table 3). The calculated consistency ratio (CR) is equal to 0.1 , therefore, the pairwise comparison matrix is consistent.

(Figure 6 and Table 3)

All five TLs were combined in the ArcGIS environment using the weighted overlay tool that multiplies several layers by their corresponding given weight values and adds them together. The geothermal surface manifestations and seismic activity are the principal indications of areas of geothermal potential because these are based on pre-existing data that are directly indicative of geothermal activity. The surface manifestations, including volcanoes, hot springs, and geysers, were assigned the maximum influence value of $38.8 \%$. Faults and seismic activity were each assigned an influence of $20.7 \%$ per layer, as these features also directly relate to the occurrence of geothermal areas. The geology layer was assigned a weight of $10.1 \%$, and the heat flow TLs are assigned an influence of $9.7 \%$ for each layer. The heat flow had the lowest influence as this parameter was based on data estimated using geophysical techniques. The weighted overlay of the various TL evidence produced an overall geothermal potential map of Africa with a range of values. The final geothermal potentiality map was classified using the Jenks natural breaks method which reduces the variance within classes and maximizes the differences between classes. Higher values indicate zones of high geothermal potential, whereas lower values suggest low potential zones (Figure 7). The resultant geothermal potential map is a guide to the priority for geothermal exploration in the future.

To validate our findings, we used known geothermal wells in different countries to reliably verify the resultant geothermal potential map. Wells with high calculated heat flow values correspond to regions of high-ranked geothermal potential in our resulting map. Furthermore, our findings were compared to those of earlier studies conducted in various regions of the African continent. Limberger et al. 2018 used global heat flow data to discuss surface heat flow; their main areas of geothermal prospectivity in Africa (i.e., northwestern and eastern Africa) are broadly in good agreement with our study. A key difference between their study approach and ours is that we have also integrated constraints from surface thermal manifestations to confirm and constrain the most prospective areas.

Furthermore, Macgregor (2020) investigated the distribution of the geothermal gradient and heat flow across the African plate. His paper showed direct heat flow and geothermal gradient data from deep wells and are very localized and cannot be extrapolated to other regions that have no direct data in Africa. The current study shows geothermal heat flow data for the African continent and has the potential to help reduce exploration costs and time and, instead, allow future researchers to focus on high-potential zones. In addition, the GIS model can be further modified and updated to accommodate any new geoscientific data as it becomes available.

(Figure 7) 


\section{Conclusions}

In total, five TL of evidence: (1) geological TL, (2) structural TL, (3) volcanic and geothermal manifestation TL, (4) seismic activity TL, and (5) heat flow TL were used to map the geothermal potential of the African continent. The different TL of evidence were assigned weights and incorporated within a GIS model to map the overall potential of geothermal resources across Africa. Note that determining the weight value and criteria for each TL forms a crucial step in this approach and exerts a major influence on the resulting map. This was performed by taking into account the opinions of geothermal experts, existing literature, and the characteristics of the study area.

The resulting geothermal potential map of Africa shows 14 regions of high geothermal potential, which could be used for further geothermal reconnaissance, exploration investigations, and development. These 14 high-potential geothermal regions are located mainly in the northernmost of Africa, the Gulf of Aqaba and Gulf of Suez in Egypt, the Red Sea access, Liberia - Ivory Coast, Djibouti, the Main Ethiopian Rift, the Kenyan Rift, the Lake of Albert Rift (DRC - Uganda), the Lake Kivu Rift, northern Malawi, central Zambia, Namibia, and the Botswana - South Africa border.

The majority of Africa's current geothermal exploitation activities are related to the EARS zones that formed during the Neogene to Quaternary through normal faulting. The rift stretches from the intersection of Afar/Red Sea triple-junction through Mozambique, Malawi, Tanzania. Kenya, and Ethiopia. Investigations of geothermal reconnaissance in Eastern Africa showed a capability of 15,000 MW (Kombe et al., 2019). Kenya alone has operational geothermal plants, where high enthalpy fields are situated inside the axis of the Kenya rift. However, there are future plans to raise the number of geothermal establishments in Eastern Africa by over 4,000 MW through the next decade, and at present, Rwanda, Ethiopia, Djibouti, and Tanzania are making significant progress in harvesting their untapped resources of geothermal energy. In contrast, at present, geothermal activities in the North African nations are currently principally used for direct applications.

This is the first study to produce a geothermal map of Africa on this scale. The approach will allow future geoscientific data to be included to update the model and the geothermal potential map has important implications for future geothermal exploration activity on the African continent.

\section{Declarations}

\section{Acknowledgments}

This study was primarily financed by the STDF (Science and Technology Development Fund) in Egypt via a Development \& Innovation Grant entitled: "A Prospective Study on the Geothermal Potential in Egypt" (project ID: 43553).

\section{Authors' contributions}


SE: develop the idea, processing the data, methodology, visualization, writing original draft; MAZ: develop the idea, funding acquisition, methodology, resources, supervision, writing original draft; HS: develop the idea, data curation, methodology, resources, supervision, writing original draft, writing, reviewing and editing; AF: arrange different sections of the manuscript especially the geology and structure parts, writing, reviewing and editing; KS: data curation, visualization, writing, reviewing and editing. All authors read and approved the final manuscript.

\section{Funding}

The corresponding author of the paper is receiving the financial support from the Science and Technology Development Fund (STDF) in Egypt (project ID: 43553).

\section{Availability of data and materials}

The datasets used and/or analyzed during this investigation are accessible upon reasonable request from the corresponding author.

\section{Competing interests}

The authors declare that they have no competing interests.

\section{References}

1. Abdel-Fattah MI, Shendi EAH, Kaiser MF, Abuzied SM. Unveiling geothermal potential sites along Gulf of Suez (Egypt) using an integrated geoscience approach. Terra Nova. 2021;33(3):306-19.

2. Abdel Zaher M, Elbarbary S, El-Shahat A, Mesbah H, Embaby A. Geothermal resources in Egypt integrated with GIS-based analysis. J Volcanol Geotherm Res. 2018;365:1-12.

3. Abuzied SM, Kaiser MF, Shendi EAH, Abdel-Fattah MI. (2020). Multi-criteria decision support for geothermal resources exploration based on remote sensing, GIS and geophysical techniques along the Gulf of Suez coastal area, Egypt. Geothermics, 88, p.101893.

4. Ait Ouali A, Issaadi A, Maizi D, Ayadi A, Bouhdjar A. Geothermal potential in the Ouarsenis-BibanKabylie (North Central Algeria): hot spring catalogue. Arab J Geosci. 2019;12:741. https://doi.org/10.1007/s12517-019-4945-4.

5. Ali MY, Lee JH. Petroleum geology of the Nogal Basin and surrpunding area, Northern Somalia, Part 2: Hydrocarbon Potential. J Pet Geol. 2019;42:233-26.

6. Aliki C, Hatzichristos T. (2019). A GIS-based Spatial Multi-Criteria Decision Analysis: Crisp and Fuzzy Methods. AGILE 2019 -Limassol, June 17-20.

7. Al-Rashed A, Shaaban F, Yousef A. The Geothermal Regime in Sirt Basin, Libya: The Geological Role and Heat Flow Studies. Int J Geos. 2019;10:57-9.

8. Bana e, Costa CA, De Corte JM, Vansnick JC. On the mathematical foundations of MACBETH, Multiple Criteria Decision Analysis. New York: Springer; 2016. pp. 421-63. 
9. Bekele B. Review and Reinterpretation of Geophysical Data of Tendaho Geothermal Field. Geological Survey of Ethiopia, Addis Ababa, Ethiopia; 2012.

10. Bello R, Ofoha CC, Wehiuzo N. (2017). Geothermal Gradient, Curie Point Depth and Heat Flow Determination of Some Parts of Lower Benue Trough and Anambra Basin, Nigeria, Using High Resolution Aeromagnetic Data. Phys. Sci. Int. J., 1-11.

11. Bhattacharyya BK, Leu LK. Spectral analysis of gravity and magnetic anomalies due to rectangular prismatic bodies. Geophysics. 1977;42(1):41-50.

12. Brownfield ME, Charpentier RR. Assessment of the undiscovered oil and gas of the Senegal Province, Mauritania, Senegal, the Gambia, and Guinea-Bissau, Northwest Africa 25. Denver: US Department of the Interior, US Geological Survey; 2003.

13. Carranza EJM, Wibowo H, Barritt SD, Sumintadireja P. Spatial data analysis and integration for regional-scale geothermal mapping. West Java Indonesia Geothermics. 2008;3:267-99.

14. Chiozzi PM, Verdoya M. Heat-flow anomaly and residual topography in the Mascarene hotspot swell (Indian Ocean). Int J Earth Sci. 2018;107:35-51.

15. Dhansay T, Wit M, Patt A. An evaluation for harnessing low-enthalpy geothermal energy in the Limpopo Province, South Africa. S. Afr J Sci. 2014;110:1-10.

16. Elbarbary S, Zaher MA, Mesbah H, El-Shahat A, Embaby A. Curie point depth, heat flow and geothermal gradient maps of Egypt deduced from aeromagnetic data. Renew Sustain Energy Rev. 2018;91:620-9.

17. Enerdata. (2013). Global Energy Statistical Yearbook, Enerdata, Grenoble, France. Available at: http://www.enerdata.net/enerdatauk/press-and-publica-tion/publications/world-energy-statisticssupply-and-demand.php.

18. ENSN. Egyptian National Seismological Network. Annual Seismological Bulletin. Egypt: National Research Institute of Astronomy and Geophysics, Cairo; 2014.

19. Esri. (2020). https://desktop.arcgis.com/en/arcmap/10.3/tools/spatial-analyst-toolbox/applyingfuzzy-logic-to-overlay-rasters.htm.

20. Evans TR, Tammemagi HY. Heat flow and heat production in northeast Africa. Earth Planet Sci Lett. 1974;23:349-56.

21. Getech. (1992). The African Magnetic Mapping Project. Commercial Report (unpublished).

22. Githiri JG, Patel JP, Barongo JO, Karanja PK. Spectral analysis of ground magnetic data in Magadi area, Southern Kenya Rift. Tanz J Sci. 2012;38:1-14.

23. Green CM, Barritt SD, Fairhead JD, Misener DJ. (1992). The African magnetic mapping project. Extended abstract. European Association of Geoscientists and Engineers (EAGE) 54th Meet Technical Exhibition, Paris.

24. Hafner M, Tagliapietra S, de Strasser L. Prospects for Renewable Energy in Africa. In: Energy in Africa. Springer Briefs in Energy. Cham: Springer; 2018. pp. 47-75. 
25. Hanano M. (2000). Two different roles of fractures in geothermal development. Proc. of the World Geothermal Congress, Kyushu-Tohoku, Japan, 2597-2602.

26. Hodgson N, Rodriguez K, Intawong A. (2017). The Angle of the North - Shallow water oil is hidden in plain sight in North Gabon. GEO ExPro. April. 52-53.

27. Horton F, Hacker B, Kylander-Clark A, Holder R, Jöns N. Focused radiogenic heating of middle crust caused ultrahigh temperatures in southern Madagascar. Tectonics. 2016;35:293-314.

28. Intawong A, Huuse M, Hodgson N, Rodriguez K. (2014). De-risking source rock maturity in the Luderitz Basin using near-surface geothermal estimates and basin modelling. Conference: PETEX Conference, London, UK.

29. Jones MQW. Heat flow anomaly in Lesotho: implications for the southern boundary of the Kaapvaal craton. Geophys Res Lett. 1992;19:2031-4.

30. Kato V. (2018). Drilling Geothermal Investigation Surveys in Uganda, Proceedings, 7th African Rift Geothermal Conference Kigali, Rwanda 31st October -2nd November.

31. Kebede F, Kulhanek O. Recent seismicity of the East African Rift system and its implications. Phys Earth Planet Inter. 1991;68:259-73.

32. Key RM. An introduction to the crystalline basement of Africa. Special Publications, 66. London: Geological Society; 1992. pp. 29-57.

33. Kombe EY, Muguthu J. Geothermal Energy Development in East Africa: Barriers and Strategies. J Energy Res Rev. 2019;2:1-6.

34. Kopylova MG, Gurney JJ, Daniels LRM. Mineral inclusions in diamonds from the River Ranch kimberlite, Zimbabwe. Contrib Mineral Petrol. 1997;129:366-84.

35. Leseane K, Atekwana EA, Mickus KL, Abdelsalam MG, Shemang EM, Atekwana EA. Thermal perturbations beneath the incipient Okavango Rift Zone, northwest Botswana. J Geophys Res Solid Earth. 2015;120:1210-28.

36. Lesquer A, Villeneuve JC, Bronner G. Heat flow data from the western margin of the West African craton (Mauritania). Phys Earth Planet Inter. 1991;66:320-9.

37. Limberger J, Boxem T, Pluymaekers M, Bruhn D, Manzella A, Calcagno P, Beekman F, Cloetingh S, van Wees J-D. Geothermal energy in deep aquifers: A global assessment of the resource base for direct heat utilization. Renew Sustain Energy Rev. 2018;82:961-75. http://dx.doi.org/10.1016/j.rser.2017.09.084.

38. Lucazeau F, Rolandone F. Heat-flow and subsurface temperature history at the site of Saraya (eastern Senegal). Solid Earth Discuss. 2012;4:599-626.

39. Macgregor DS. Regional variations in geothermal gradient and heat flow across the African plate. $J$ Afr Earth Sc. 2020;171:103950. https://doi.org/10.1016/j.jafrearsci.2020.103950.

40. Maden N. Curie-point depth from spectral analysis of magnetic data in Erciyes stratovolcano (Central TURKEY). Pure Appl Geophysi. 2010;167:349-58. 
41. Matende KN. (2015). Magnetic under-plating beneath Luangwa Rift Valley, Zambia, Thesis, Faculty of the Graduate College of the Oklahoma State University, 88p.

42. Meghraoui M, Amponsah P, Ayadi A, Ayele A, Ateba B, Bensuleman A, Delvaux D, Gabry E, Fernandes M, Midzi R-M, Roos V, Timoulali M. Y., IGCP-601 Working Group The seismotectonic map of Africa. Episodes. 2016;39(1):9-18.

43. Meliani O, Bourmatte A, Hamoudi M, Haddoum H, Quesnel Y. Moho depth derived from gravity and magnetic data in the Southern Atlas Flexure (Algeria). J Afr Earth Sci. 2016;121:100-7.

44. Meng F, Liang X, Xiao C, Wang G. Geothermal resource potential assessment utilizing GIS - based multi-criteria decision analysis method. Geothermics. 2021;89:101969.

45. Mohamed AY, Whiteman AJ, Archer SG, Bowden SA. Thermal modelling of the Melut basin Sudan and South Sudan: Implications for hydrocarbon generation and migration. Mar Pet Geol. 2016;77:746-62.

46. Mono JA, Ndougsa-Mbarga T, Tarek Y, Ngoh JD, Amougou OUIO. Estimation of Curie-point depths, geothermal gradients and near-surface heat flow from spectral analysis of aeromagnetic data in the Loum-Minta area (Centre-East Cameroon). Egypt J Pet. 2018;27:1291-9.

47. Mraidi I, Asmi ME, Skanji A, A. Conductivity and Temperature Corrections in the Djeffara Basin (Tunisia): Impact of the Basin Heat Flow Reconstructions. In: Banerjee S, Barati R, Patil S, editors. Advances in Petroleum Engineering and Petroleum Geochemistry. CAJG 2018. Advances in Science, Technology \& Innovation. Cham: Springer; 2019. https://doi.org/10.1007/978-3-030-01578-7_23.

48. Mumba R, Mabedi E, Kalebe Y. (2018). Aero-Magnetic Surveys for Geothermal Exploration in Malawi. Proceedings, 7th African Rift Geothermal Conference Kigali, Rwanda 31st October -2nd November.

49. Njinju EA, Kolawole F, Atekwana EA, Stamps DS, Atekwana EA, Abdelsalam MG, Mickus KL. Terrestrial heat flow in the Malawi Rifted Zone, East Africa: Implications for tectono-thermal inheritance in continental rift basins. J Volcanol Geotherm Res. 2019;387:106656.

50. Noorollahi Y, Itoi R, Fujii H, Tanaka T. GIS model for geothermal resource exploration in Akita and Iwate prefectures, northern Japan. Comput Geosci. 2007;33:1008-21.

51. Nyblade AA, Pollack HN. Can differences in heat flow between east and southern Africa be easily interpreted? Implications for understanding regional variability in continental heat flow. Tectonophysics. 1993;219:257-72.

52. Okubo Y, Graf RJ, Hansen RO, Ogawa K, Tsu H. Curie point depths of the Island of Kyushu and surrounding areas. Japan Geophysics. 1985;53(3):481-94.

53. Persits FM, Ahlbrandt TS, Tuttle ML, Charpentier RR, Brownfield ME, Takahashi KI. (1997). Maps showing geology, oil and gas fields and geological provinces of Africa: U.S. Geological Survey OpenFile Report 97-470-A, https://doi.org/10.3133/ofr97470A.

54. Perzina R, Ramíka J. Microsoft Excel as a tool for solving multicriteria decision problems. Procedia Computer Science. 2014;35:1455-63.

55. Poux B, Suemnicht G. (2012). Use of GIS Geoprocessing to Select the Most Favorable Sites for Geothermal Exploration in Oregon, Geothermal Resources Council Annual Meeting 2012 (GRC 2012), 
Reno, Nevada, USA 30 September - 3 October, 745-750.

56. Prol-Ledesma RM. Evaluation of the reconnaissance results in geothermal exploration using GIS. Geothermics. 2020;29:83-103.

57. Rimi A, Fernandez M, Manar A, Matsushima J, Okubo Y, Morel JL, Winckel A, Zeyen H. (2005). Geothermal anomalies and analysis of gravity, fracturing and magnetic features in Morocco. World Geothermal Congress (2005), Antalya, 24-29 April, 1-10.

58. Rimi A, Lucazeau F. (1987). Heat flow density measurements in northern Morocco. J. Afr. Earth Sci., (1983) 6, 835-843.

59. Ring U. The East African Rift System. Austrian J Earth Sci. 2014;107/1:132-46.

60. Rutagarama U. (2016). Geothermal exploration in Rwanda. SDG Short Course I on Exploration and Development of Geothermal Resources, organized by UNU-GTP, GDC and KenGen, at Lake Bogoria and Lake Naivasha, Kenya, Nov. 10-31.

61. Saaty TL. How to Make a Decision: The Analytic Hierarchy Process. Interfaces. 1994;24(6):19-43.

62. Saaty TL. (1988) What is the Analytic Hierarchy Process?. In: Mitra G., Greenberg H.J., Lootsma F.A., Rijkaert M.J., Zimmermann H.J, editors Mathematical Models for Decision Support. NATO ASI Series (Series F: Computer and Systems Sciences), vol 48. Springer, Berlin, Heidelberg.

63. Saaty TL. A scaling method for priorities in hierarchical structures. J Math Psychol. 1977;15(3):23481.

64. Saibi A, Ehara S, Fujimitsu Y, Nishijima J. Progress of geothermal development in Algeria. Journal of Geothermal Research Society of Japan. 2006;28(4):383-97.

65. Saleh S, Salk M, Pamukçu O. Estimating Curie point depth and heat flow map for northern Red Sea rift of Egypt and its surroundings, from aeromagnetic data. Pure Appl Geophys. 2013;170:863-85.

66. Sass JH, Behrendt JC. Heat flow from the Liberian Precambrian shield. J Geophys Res Solid Earth. 1980;85:3159-62.

67. Schito A, Corrado S, Aldega L, Grigo D. Overcoming pitfalls of vitrinite reflectance measurements in the assessment of thermal maturity: the case history of the lower Congo basin. Mar Pet Geol. 2016;74:59-70.

68. Seipold U. Depth dependence of thermal transport properties for typical crustal rocks. Phys Earth Planet Inter. 1992;69:299-303.

69. Sinzinkayo JM, Sliwa T, Wakana F. (2015). Directions of Energy Balance Improvement in Burundi in the Aspect of Geothermal Energy Resources. Proc. World Geothermal Congress (2015), Melbourne, Australia, 19-25 April.

70. Spector A, Grant FS. Statistical models for interpreting aeromagnetic data. Geophysics. $1970 ; 35(2): 293-302$.

71. Thiéblemont D, Liégeois JP, Fernandez-Alonso M, Ouabadi A, Le Gall B, Maury R, Jalludin M, Vidal M, Ouattara G, Tchaméni R, Michard A, Nehlig P, Rossi P, Chêne F. Geological map of Africa at 1:10 M scale. CGMW-BRGM; 2016. 
72. Teklemariam Z. Geothermal outlook in East Africa and contribution of UNU-GTP in capacity building, UNU-GTP 40th Anniversary Workshop. Iceland: Reykjavik; 2018. 10 pp.

73. Trumpy E, Donato A, Gianelli G, Gola G, Minissale A, Montanari D, Santilano A, Manzella A. Data integration and favourability maps for exploring geothermal systems in Sicily, southern Italy. Geothermics. 2015;56:1-16.

74. Tüfekci N, Suzen ML, Gulec N. GIS based geothermal potential assessment: A case study from Western Anatolia, Turkey. Energy. 2010;35:246-61.

75. Wafula DM. Impacts of tectonic earthquakes in the Western Rift Valley of Africa on the volcanic activity of Nyiragongo, Virunga region. Asian J Sci Res. 2011;4:209-23.

76. Wang Y, Liu L, An F, Wang H, Pang X. Maturation history modeling of Sufyan Depression, northwest Muglad Basin, Sudan. J Afr Earth Sci. 2016;120:70-6.

77. Waring GA. (1983). Thermal springs of the united states and other countries of the world - A summary. Geological Survey professional Paper 492. United States Department of the Interior. USGS.

78. Wheildon J, Morgan P, Williamson KH, Evans TR, Swanberg CA. Heat flow in the Kenya rift zone. Tectonophysics. 1994;236:131-49.

79. Yalcin M, Gul FK. A GIS-based multi criteria decision analysis approach for exploring geothermal resources: Akarcay basin (Afyonkarahisar). Geothermics. 2017;67:18-28.

80. Yousefi H, Noorollahi Y, Ehara S, Itoi R, Yousefi A, Fujimitsu Y, Nishijima J, Sasaki K. Developing the geothermal resources map of Iran. Geothermics. 2010;39:140-51.

\section{Tables}

Table 1. The fundamental scale of the analytic hierarchy process (AHP) (Saaty, 1994)

Intensity of $\quad$ Definition
importance on
an absolute

$1 \quad$ Equal importance

3

Moderate importance of one over another

5

Essential or strong importance

7

Very strong importance

9

Extreme importance

$2,4,6,8$

Intermediate values between the two adjacent judgments

Reciprocals

If activity "i" has one of the above numbers assigned to it when compared with activity " $\mathrm{j}$ ", then " $\mathrm{j}$ " has the reciprocal value when compared with " $\mathrm{i}$ ". $\mathrm{i}$ and $\mathrm{j}$ are subscripts of " $x$ " in Equation (1). 
Table 2. Geothermal activities, temperature gradients, and heat flows of some African countries based on various previous work.

*(EAR) East African Rift, other major fault-controlled (F), indirect use (IU) with potential for electricity production, direct use (DU), existing power plants (PP), exploration stages (ES). Avg: Average.

Table 3. Judgment matrix and weights of criteria.

\begin{tabular}{|c|c|c|c|c|c|c|}
\hline & $\begin{array}{l}\text { Distance to } \\
\text { surface } \\
\text { mainfestations }\end{array}$ & $\begin{array}{l}\text { Geologic } \\
\text { units }\end{array}$ & $\begin{array}{l}\text { Distance } \\
\text { to faults }\end{array}$ & $\begin{array}{l}\text { Distance to } \\
\text { seismic } \\
\text { activity }\end{array}$ & $\begin{array}{l}\text { Heat } \\
\text { flow } \\
\text { from } \\
\text { CPD }\end{array}$ & Weights \\
\hline $\begin{array}{l}\text { Distance to } \\
\text { surface } \\
\text { mainfestations }\end{array}$ & 1 & 2 & 3 & 3 & 3 & $38.8 \%$ \\
\hline Geologic units & $1 / 2$ & 1 & $1 / 2$ & $1 / 2$ & $1 / 2$ & $10.1 \%$ \\
\hline $\begin{array}{l}\text { Distance to } \\
\text { faults }\end{array}$ & $1 / 3$ & 2 & 1 & 1 & 4 & $20.7 \%$ \\
\hline $\begin{array}{l}\text { Distance to } \\
\text { seismic activity }\end{array}$ & $1 / 3$ & 2 & 1 & 1 & 4 & $20.7 \%$ \\
\hline $\begin{array}{l}\text { Heat flow from } \\
\text { CPD }\end{array}$ & $1 / 3$ & 2 & $1 / 4$ & $1 / 4$ & 1 & $9.7 \%$ \\
\hline
\end{tabular}

\section{Figures}

\section{Figure 1}

Surface geothermal manifestations and volcanic activities in the African continent

Figure 2

Flow chart of the approach utilized to produce a geothermal potential map of Africa continent.

\section{Figure 3}

Surface geological map of African continent, scale 1:10 million (Thiéblemont et al., 2016). The rock units were arranged into clastic sedimentary, carbonate, and Precambrian rocks depending on their thermal 


\begin{tabular}{|c|c|c|c|c|}
\hline Country & $\begin{array}{l}\text { *Geothermal } \\
\text { Activities }\end{array}$ & $\begin{array}{l}\text { Geothermal } \\
\text { Gradient } \\
\left({ }^{\circ} \mathrm{C} / \mathrm{km}\right)\end{array}$ & $\begin{array}{l}\text { Heat Flow } \\
(\mathrm{mW})\end{array}$ & Reference \\
\hline Algeria & DU & & $100-120$ & (Meliani et al., 2016) \\
\hline Botswana & $\mathrm{DU}, \mathrm{F}$ & & $60-90$ & (Leseane et al., 2015) \\
\hline Burundi & DU, ES, EAR & $>60$ & 72 & (Sinzinkayo et al., 2015) \\
\hline Cameroon & & $\begin{array}{l}\text { Avg of } \\
72.24\end{array}$ & $\begin{array}{l}\text { Avg of } \\
180.59\end{array}$ & (Mono et al., 2018) \\
\hline Congo & & 40 & $30-140$ & (Schito et al., 2016) \\
\hline Djibouti & $\begin{array}{l}\text { IU, DU, EAR, } \\
\text { ES }\end{array}$ & & $\sim 235$ & (Saleh et al., 2013) \\
\hline Egypt & DU & $\begin{array}{l}16.3 \text { to } \\
67.4\end{array}$ & $\begin{array}{l}47.1- \\
195.5\end{array}$ & $\begin{array}{l}\text { (Abdel Zaher et al., 2018; Elbarbary et } \\
\text { al., 2018) }\end{array}$ \\
\hline Ethiopia & $\begin{array}{l}\text { IU, DU, EAR, } \\
\text { ES, PP }\end{array}$ & 60 & & (Bekele, 2012) \\
\hline Gabon & & Avg 33 & & (Hodgson et al., 2017) \\
\hline Gambia & & Avg 30 & & (Brownfield \& Charpentier, 2003) \\
\hline Ghana & & & $42 \pm 8$ & (Sass \& Behrendt, 1980) \\
\hline Guinea & & Avg 30 & & (Brownfield \& Charpentier, 2003) \\
\hline $\begin{array}{l}\text { Guinea- } \\
\text { Bissau }\end{array}$ & & Avg 30 & & (Brownfield \& Charpentier, 2003) \\
\hline Kenya & $\begin{array}{l}\text { IU, DU, EAR, } \\
\text { ES, PP }\end{array}$ & $\begin{array}{l}69.92- \\
111.53\end{array}$ & $40-42$ & $\begin{array}{l}\text { (Githiri et al., 2012; Wheildon et al., } \\
\text { 1994) }\end{array}$ \\
\hline Lesotho & & $12-21$ & $43-49$ & (Jone,s 1992) \\
\hline Liberia & & & $38-42$ & (Sass \& Behrendt, 1980) \\
\hline Libya & DU & $40->60$ & $80-130$ & (Al-Rashed et al., 2019) \\
\hline Madagascar & DU,IU & & $\begin{array}{l}65-76 \text { in } \\
\text { the west } \\
65-114 \text { in } \\
\text { the east }\end{array}$ & (Horton et al., 2016) \\
\hline Malawi & DU, EAR, ES & $25-27$ & $60-66$ & (Njinju et al., 2019; Numba et al., 2018) \\
\hline Mauritania & & $22-28$ & 50 & (Lesquer et al., 1991) \\
\hline Mauritius & & & $61 \pm 18$ & (Chiozzi \&Verdoy,a 2018) \\
\hline
\end{tabular}




\begin{tabular}{|c|c|c|c|c|}
\hline Morocco & DU & $35-50$ & 80 to 110 & $\begin{array}{l}\text { (Rimi et al., 2005; Rimi \& Lucazeau, } \\
\text { 1987) }\end{array}$ \\
\hline Mozambique & DU & & $47 \pm 4$ & (Nyblade \& Pollack 1993) \\
\hline Namibia & $\mathrm{DU}, \mathrm{F}$ & & $40-60$ & (Intawong et al., 2014) \\
\hline Nigeria & & 32.1 & $63-97.3$ & (Bello et al., 2017)) \\
\hline Rwanda & $\begin{array}{l}\text { IU, DU, EAR, } \\
\text { ES }\end{array}$ & $\sim 30$ & & (Rutagarama, 2016) \\
\hline Senegal & & Avg 30 & $29-33$ & $\begin{array}{l}\text { (Brownfield \& Charpentier, 2003; } \\
\text { Lucazeau \& Rolandone, 2012) }\end{array}$ \\
\hline Somalia & & $\sim 35-49$ & $58 \pm 12$ & $\begin{array}{l}\text { (Ali \& Lee, 2019; Evans \& Tammemagi, } \\
\text { 1974) }\end{array}$ \\
\hline South Africa & DU & $29-32$ & $70-82$ & ( Njinju et al., 2019) \\
\hline South Sudan & & & Avg 59 & (Mohamed et al., 2016) \\
\hline Sudan & DU & $20-26$ & Avg 39 & (Wang et al., 2016) \\
\hline Tanzania & $\begin{array}{l}\text { IU, DU, EAR, } \\
\text { ES }\end{array}$ & & 34 & (Nyblade \& Pollack, 1993) \\
\hline Tunisia & DU & $23-49$ & 82 & (Mraidi et al., 2018) \\
\hline Uganda & $\begin{array}{l}\text { IU, DU, EAR, } \\
\text { ES }\end{array}$ & $27-31$ & $\begin{array}{l}67-79 \pm \\
0.2\end{array}$ & (Kato, 2018) \\
\hline Zambia & $\begin{array}{l}\text { ES, DU, IU, } \\
\text { EAR }\end{array}$ & $\sim 23$ & $46-78$ & (Matende 2015) \\
\hline Zimbabwe & & & $41-42$ & (Kopylova et al., 1997) \\
\hline
\end{tabular}

conductivity properties. Lines represent surface faults.

\section{Figure 4}

Distribution of earthquake epicenters in Africa that have depths less than $10 \mathrm{~km}$ with magnitudes from 1 to 6. Data collected from the International Seismological Center, the USGS, and the Egyptian Seismological Center.

\section{Figure 5}

Heat flow map of Africa estimated from spectral analyses of aeromagnetic data. Colored circles showing heat flow from deep wells in various African countries were plotted to corroborate our findings. 


\section{Figure 6}

Standardization of the five criteria layers based on decision maker's experience-based suitability evaluation; (A) geologic units, (B) distance to fault lines, (C) distance to surface manifestations, (D) distance to epicenters, and (E) heat flow.

\section{Figure 7}

Geothermal potential map of Africa derived from the weighting of overlays, each representing analyses of thematic layers. 